\title{
Evaluation of Indonesian selected macroalgae for their antitumor and cytoprotective activity
}

Eka Sunarwidhi Prasedya ${ }^{1,2}$, Mutiadevi Ariyana ${ }^{1}$, Candra Dwipayana Hamdinn ${ }^{1}$, Aluh Nikmatullah ${ }^{1}$, Susumu Yoshie ${ }^{2}$, Masao Miyake ${ }^{2}$, Daisuke Kobayashi², Akihiro Hazama², Haji Sunarpi ${ }^{1 *}$

${ }^{1}$ Bioscience and Biotechnology Research Centre, Faculty of Mathematics and Natural Sciences, Mataram University, Mataram, Indonesia.

${ }^{2}$ Department of Cellular and Integrative Physiology Fukushima Medical University, Fukushima, Japan.

\section{ARTICLE INFO \\ Received on: 10/07/2018 \\ Accepted on: 20/10/2018 \\ Available online: 30/11/2018}

\section{Key words:}

Antiproliferative, cancer, cytotoxicity, Indonesia,

macroalgae, ultraviolet.

\begin{abstract}
Context: Macroalgae are known to exhibit secondary metabolites with interesting bioactive properties, including antibacterial, antioxidant, antitumor, and anti-UV effects. Indonesia is endowed with an abundance of macroalgae, yet information regarding their pharmaceutical properties remains largely unexplored.

Objective: This study evaluates the antitumor and cytoprotective effects of Indonesian selected seaweeds Acanthophora spicifera (ASE), Acanthophora muscoides (AME), Sargassum polycystum (SPE), and Sargassum crassifolium (SCE) crude ethanol extracts.

Materials and Methods: Preliminary phytochemical screening was used to determine chemical constituents in macroalgae ethanol extracts. Cytotoxicity and antiproliferative activity of macroalgae extracts were evaluated with Methyl Thiazolyl Tetrazolium (MTT) assay from 5 to $200 \mu \mathrm{g} / \mathrm{ml}$ concentration in human cervical cancer (HeLa) and human umbilical vein endothelium (HUVEC) cells for 72 hours. UV absorbing capabilities of macroalgae extracts were determined with UV-VIS $(240-340 \mathrm{~nm})$. Cytoprotective effects were evaluated by fluorescence microscopy observation of cells irradiated with UV-B for 3 minutes.

Results: AME appeared to exhibit most diverse chemical constituents. Only ASE and AME demonstrated moderate cytotoxicity $\left(\mathrm{ASE}-\mathrm{IC}_{50}=190 \pm 24 \mu \mathrm{g} / \mathrm{ml}\right.$; $\mathrm{AME} \mathrm{IC}_{50}=180 \pm 14 \mu \mathrm{g} / \mathrm{ml}$ ) against HeLa cells in 72 hours incubation. Furthermore, the cytotoxicity effects of all macroalgae extracts could not be detected in HUVEC cells at tested concentrations. In addition, SPE and SCE potentially reduced nuclear DNA damage induced by UV-B radiation.

Conclusion: Current results show Indonesian macroalgae possesses a broad range of possible therapeutic applications. Therefore, further advanced studies relating to the isolation of specific bioactive compounds and molecular mechanisms would be reasonable to fully utilize macroalgae potential uses in the pharmaceutical industries.
\end{abstract}

\section{INTRODUCTION}

The recent studies demonstrated the importance of natural products, both plant extracts and isolated compounds which have shown appreciable biological activities (Butler, 2004; Cragg et al., 2006). There are some terrestrial plant-derived oncology drugs which are already approved by

${ }^{*}$ Corresponding Author

Haji Sunarpi, Bioscience and Biotechnology Research Centre, Faculty of Mathematics and Natural Sciences, Mataram

University, Mataram, Indonesia,E-mail: ekajp@yahoo.com the United States Food and Drug Administration (FDA) such as vepesid, vumon, hymcatin, and Camptosar (Kintzios, 2006). However, the marine environment has provided various bioactive products that continue to show unique biological activities. Until now, the marine environment consists of three FDA approved drugs, 1 EU registered drug, 13 natural products, and a large number of marine chemicals in the pre-clinical category (Mayer et al., 2010). Another analysis showed that by the end of 2013, 307 natural products and 15 natural product derivatives from the plant, bacteria, fungi, and marine sources had been approved by the FDA or $21 \%$ of all approved new chemical entities (Patridge et al., 2015). 
Macroalgae or seaweeds have attracted the attention of the pharmaceutical industry, due to the great diversity of species that are available and the ability to produce secondary metabolites with various pharmacological activities such as cytotoxic activity, antiproliferative, antimicrobial, cytoprotective, anticoagulant, and antioxidant activities (Bouhlal et al., 2011; Heo and Jeon, 2009; Kang et al.,2012; Kim et al., 2011;2015; Na et al., 2005; Shi et al., 2010). In addition, as a mechanism to protect themselves against other organisms in their environment, macroalgae produce a wide variety of bioactive metabolites as a potential source of novel compounds for various purposes (Kawaguchi and Hayashizaki, 2011). Some of these metabolites such as iodine, carotene, glycerol, alginates, and carrageenans have been evaluated for its pharmaceutical properties (Barbosa et al., 2014; Luo et al., 2015; Prasedya et al., 2016).

Despite such advantages of natural products and a proven track record of succeeding discoveries, most pharmaceutical companies have been discouraged from pursuing natural productbased drug discovery due to perceived disadvantages of the natural products. These include challenges in ensuring access and adequate supply of potential natural product resources. Indonesia tropical warm waters are well-known as a suitable place for the macroalgae growth. Hence, it is endowed with an abundance of macroalgae (Tarman et al., 2011). However, there remains little information regarding Indonesian macroalgae pharmaceutical properties. The present study was, therefore, to evaluate pharmaceutical properties of selected macroalgae from Indonesian coastal areas; Acanthophora spicifera (ASE), Acanthophora muscoides (AME), Sargassum polycystum (SPE), and Sargassum crassifolium (SCE) crude ethanol extracts. We discovered that only ASE and AME provided selective cytotoxic activity in the human cells. However, SPE and SCE shown effectivity in the reduction of nuclear DNA damage induced by UVB radiation in human cervical cancer (HeLa) cells.

Our current results would provide preliminary information of potential pharmaceutical properties of Indonesian macroalgae for potential utilization in various medicinal applications. In addition, further advanced research regarding bioactive compound mechanisms would be reasonable for further development of macroalgae-based natural pharmaceutical products.

\section{MATERIALS AND METHODS}

\section{Sample collection and extraction}

Macroalgae samples were collected from North West Lombok area, Mentigi beach $\left(8^{\circ} 24^{\prime} 11.7396^{\prime \prime} \mathrm{S}, 116^{\circ} 4^{\prime} 1.9056^{\prime \prime} \mathrm{E}\right)$, West Nusa Tenggara Province, Indonesia at the end of 2017. Macroalgae specimens were identified according to Sulistijo (2009) and Guiry and Guiry (2018). The seaweed samples were washed with fresh water to remove adhering debris. The collected samples were then dried and powdered. Powdered samples were mixed with absolute ethanol solvent with $5 \times$ volume of sample weight $(\mathrm{w} / \mathrm{v})$. Suspensions were then macerated by incubation in room temperature for 48 hours. For every 24 hours, suspensions were filtered with Whatman number 1 filter papers. Filtrates were evaporated with rotary evaporators until concentrated ethanol extracts were obtained. These filtrates were then used for seaweed ethanol extracts.

\section{Chemicals and reagents}

Methyl Thiazolyl Tetrazolium (MTT) assaywere purchased from Dojindo Laboratories (Kumamoto, Japan), nicotinamide adenine dinucleotide was obtained from Oriental Yeast Co. Ltd. (Tokyo, Japan). General reagents including lithium lactate were purchased from Wako Pure Chemicals (Osaka, Japan).

\section{Preparation of macroalgae extract for analysis}

Macroalgae extraction with ethanol solvent was conducted according to methods by Cho et al. (2007) with small modifications. Powdered seaweed $(50 \mathrm{~g})$ was extracted successively using Soxhlet extractor sequentially with different solvents of increasing polarity of ethanol until the extract was clear. The resulting pasty extracts were stored in a refrigerator at $4^{\circ} \mathrm{C}$ for further use. The extraction was centrifuged at $15,000 \times \mathrm{g}$ for 10 minutes. The supernatant was collected, dried, and stored at $4^{\circ} \mathrm{C}$ until for future use. The dried macroalgae extract was resolved in dimethyl sulfoxide (DMSO) and centrifuged at $15,000 \times g$ for 15 minutes, and then clear macroalgae extract sample was obtained.

\section{Phytochemical profiling}

Gas chromatography-mass spectrometry (GC-MS) analysis of the ethanol extract of macroalgae extracts was performed using a Perkin-Elmer GC Clarus 500 system comprising an AOC-20i auto-sampler and a gas chromatograph interfaced to a mass spectrometer (GC-MS) equipped with an Elite-5MS (5\% diphenyl/95\% dimethyl polysiloxane) fused a capillary column $(30 \times 0.25 \mu \mathrm{m}$ ID $\times 0.25 \mu \mathrm{m} d \mathrm{f})$. Macroalgae extracts were also subjected to phytochemical screening following the methodology of Harborne (1998).

\section{Test for alkaloids}

One gram powder of macroalgae samples was taken in a conical flask and added ammonia solution $(3 \mathrm{ml})$. It was allowed to stand for few minutes to evaluate free alkaloids. Chloroform $(10 \mathrm{ml})$ was added to the conical flask shaken by hand and then filtered. The chloroform was evaporated from the crude extract by water bath and added Mayer's reagent $(3 \mathrm{ml})$. A cream color precipitation was obtained that showed the presence of alkaloids.

\section{Test for flavonoids}

The stock solution $(1 \mathrm{ml})$ was taken in a test tube and added a few drops of dilute $\mathrm{NaOH}$ solution. An intense yellow color appeared in the test tube. It became colorless when on the addition of few drops of dilute acid that indicated the presence of flavonoids.

\section{Test for saponins}

The stock solution $(1 \mathrm{ml})$ was taken in a test tube and diluted with $20 \mathrm{ml}$ of distilled water. It was shaken by hand for 15 minutes. A foam layer was obtained on the top of the test tube. This foam layer indicated the presence of saponins.

\section{Test for steroids}

The crude plant extract ( $1 \mathrm{mg})$ was taken in a test tube and dissolved with chloroform $(10 \mathrm{ml})$, then added an equal volume of concentrated sulfuric acid to the test tube by sides. The 
upper layer in the test tube turns into red and sulfuric acid layer showed yellow with green fluorescence. It showed the presence of steroids.

\section{Test for tannins}

The stock solution $(3 \mathrm{ml})$ was taken in a test tube and diluted with chloroform and added acetic anhydride $(1 \mathrm{ml})$. Finally, sulfuric acid $(1 \mathrm{ml})$ was added carefully by the side of the test tube to the solution. A green color was formed which showed the presence of tannins.

\section{Test for triterpenoids}

The dry crude plant extract $(5 \mathrm{mg})$ was dissolved in chloroform $(2 \mathrm{ml})$ and then acetic anhydride $(1 \mathrm{ml})$ was added to it. Concentrated sulfuric acid $(1 \mathrm{ml})$ was added to the solution. Formation of reddish-violet color shows the presence of triterpenoids.

\section{Cell culture}

HeLa cell lines were routinely cultivated in Dulbecco's modified Eagle medium (DMEM, Wako) supplemented with $10 \%$ fetal bovine serum at $37^{\circ} \mathrm{C}$ in a $5 \% \mathrm{CO}_{2}$ humidified incubator. HUVEC cells were cultured in MCDB131 medium supplemented with $10 \mathrm{ng} / \mathrm{ml}$ epidermal growth factor, $10 \mu \mathrm{g} / \mathrm{ml}$ heparin, and 10\% FBS. For all experiments, cells were plated in medium, incubated overnight, and incubated in specific medium supplemented with various concentrations $(5-200 \mu \mathrm{g} /$ $\mathrm{ml}$ ) of macroalgae extracts. Cell images were obtained from phase-contrast microscopy by BZ-9000 microscope (Keyence, Osaka, Japan).

\section{Cytotoxicity assay}

Cytotoxicity activity of macroalgae samples was estimated by methyl thiazolyl tetrazolium (MTT) assay. Cells were cultured in 96-well culture plate over-night, then the culture mediums were discarded and changed with new medium containing several concentrations of macroalgae ethanol extracts (5-200 $\mu \mathrm{g} /$ $\mathrm{ml}$ ). Cell counting was performed with FlexStation 3 multi mode microplate reader at an absorbance of $450 \mathrm{~nm}$. Cytotoxicity was calculated by the following equation:

$$
\text { Cytotoxicity }(\%)=\frac{\left(A_{450 \text { treatment }}-A_{450 \text { min }}\right)}{\left(A_{450 \text { max }}-A_{450 \text { min }}\right)} \times 100 \% \text {. }
$$

\section{Absorption of UV-B by macroalgae extracts}

For UV-VIS spectrophotometer analysis, the extracts were centrifuged at 3,000 rpm for 10 minutes and filtered through Whatman No. 1 filter paper by using a high-pressure vacuum pump. The sample is diluted to $1: 10$ with the same solvent. The crude extracts containing the bioactive compound were analyzed spectroscopically for further confirmation. To detect the UV-VIS spectrum profile of the crude macroalgae ethanol extracts, the extracts were scanned in the wavelength ranging from 200 to $1,100 \mathrm{~nm}$ by using NanoDrop 2000c spectrophotometer, Thermo Scientific, and the characteristic peaks were detected.

\section{HeLa cell exposure to UV-B irradiation}

HeLa cells were cultured in DMEM while the cells adhered to the dish, and thereafter, the medium was changed to DMEM with $20 \mu \mathrm{g} / \mathrm{ml}$ of macroalgae extracts. Followed by subsequent ultraviolet radiation ( $302 \mathrm{~nm}$ ) for 3 minutes by using UV trans-illuminator (ChemiDoc XRS+, Bio-Rad Laboratories, Inc., Hercules). After the radiation treatment, the cells were incubated at $37^{\circ} \mathrm{C}$ for an additional 24 hours. Double staining with $1 \mu \mathrm{g} / \mathrm{ml}$ propidium iodide (PI) and $1 \mu \mathrm{M}$ Hoechst 33342 was conducted to differentiate live and dead cells. Cell image was obtained from red fluorescence (PI-staining as a dead cell) and blue fluorescence (Hoechst 33342-staining as a total cell) view by BZ-9000. UVdamage was estimated as the ratio of dead cells to total cells.

\section{Statistical analysis}

The results were expressed as means \pm standard error of the mean (SEM), and experiments were conducted at least in triplicate $(n=3)$. Significant differences were assessed with analysis of variance followed by post-hoc test LSD and Tukey-HSD, $p<0.05$ was considered as statistically significant, and SPSS statistical package for Windows (release 15.0, SPSS Inc., Chicago, IL) was used.

\section{RESULTS}

\section{Phytochemical profile of macroalgae ethanol extracts}

Investigation of the ethanol macroalgae extracts with GC-MS analysis led to the identification of potential bioactive compounds. Seven main compounds were seen in AS and AM ethanol extracts. The main compounds identified in ASE were palmitic acid (9.24\%) and Heptadecene-(8)-carbonic acid $(9.77 \%)$. Whereas, AME shown the more diverse presence of main compounds, such as $\beta$-copaen-4. $\alpha$-ol (3.47\%), 1-Naphthalenamine, 4-bromo (9.77\%), valerenal (11.48\%), palmitic acid (12.01\%), and 2,3,5-Tribomo-N-methylindole (12.91\%). SPE and SCE shown similar chemical constituents, the dominant compounds were palmitic acid and stearic acid. This result was also confirmed by a phytochemical screening of macroalgae ethanol extracts which shown the presence of alkaloids, terpenoids, steroids, tannins, and saponins. However, the existence of these compounds varies between the macroalgae species. All macroalgae ethanol extracts exhibited the presence of steroids. However, flavonoids were absent in all macroalgae ethanol extracts. Alkaloid constituents were present in all macroalgae ethanol extracts except in SPE. Overall, AME and SCE revealed the most promising profile of phytochemical constituents.

\section{Cytotoxicity assay}

Cytotoxicity effects of macroalgae ethanol extracts were investigated via MTT assay against HeLa cell line and HUVEC cell line. After 72 hours treatment, only ASE and AME shown cytotoxic effects against HeLa cell lines with $\mathrm{IC}_{50}$ of $190 \pm 24 \mu \mathrm{g} / \mathrm{ml}$ and $180 \pm 14 \mu \mathrm{g} / \mathrm{ml}$, respectively. Furthermore, the cytotoxicity effects of all macroalgae ethanol extracts could not be detected in HUVEC cells in all tested concentrations. Treatment with macroalgae ethanol extracts of concentration over $200 \mu \mathrm{g} / \mathrm{ml}$ resulted in some debris which appeared in the culture medium; therefore, we could not perform higher concentration in this study. 


\section{Cell morphology}

To assess the alterations of cell morphology, subsequent to treatments of macroalgae ethanol extracts, cells were grown on 35-mm glass bottom culture dish for microscopy observation. Untreated HeLa cells were homogeneously distributed, exhibit an elongated shape, observed by phase-contrast microscopy (Fig. 3). However, ASE and AME treated cells resulted in cell morphology changes. Cells were seen to lose cell membrane integrity which could potentially lead to cell death. The alterations induced by the treatment included reduction of cell size, cell shrinkage, and the formation of blebs on cell surface resulted in the generation of apoptotic bodies. These cytotoxicity features were not detected in HeLa cells treated with SPE and SCE. In addition, all macroalgae extracts did not affect cell morphology in HUVEC cells in tested concentrations.

\section{Macroalgae ethanol extracts UV absorption analyses}

In addition to macroalgae ethanol extracts anti-tumoral effects, in this study, we intended to investigate the cytoprotective activity of macroalgae ethanol extracts against UV radiation. The extracts were dissolved in DMSO, and the extract solution was diluted in water to a concentration of $20 \mu \mathrm{g} / \mathrm{ml}$. A wavelength from 280 to $380 \mathrm{~nm}$ is UV and UV absorption of the macroalgae ethanol extracts was measured (Fig. 4). ASE and DMSO $0.5 \%$ for solvent control resulted in absorbance peak close to the baseline. Whereas AM, SPE, and SCE showed considerable capability in UV absorption in the UV-B spectrum region (280-315 nm).

\section{Cytoprotective activity analyses of macroalgae ethanol extracts against $U V-B$ radiation}

The HeLa cells were cultured in DMEM with and without $20 \mu \mathrm{g} / \mathrm{ml}$ of macroalgae ethanol extracts for 24 hours after 3 minutes of UV-B radiation. Figure 5 shows double staining of 24 hours treated HeLa cells with Hoechst 33342/PI. HeLa cells treated with UV-B radiation resulted in severe morphological changes such as elongated and thin shaped. Furthermore, AME, SPE, and SCE demonstrated the potential cytoprotective effect in cellular DNA against UV-B radiation. This was shown by the significant lower percentage of dead cells (PI-stained cells) incubated with AME, SPE, and SCE compared with cells applied with ASE and control + UV cells (Fig. 6).

\section{DISCUSSION}

Seaweed has reportedly to contain various compounds with various biological activities such as sulfated polysaccharides, polyphenols, and phlorotannins (Alekseyenko et al., 2007; Pavia and Brock 2000; Pavia et al., 1997). In recent years, many researchers have worked to study potential biological activities of seaweeds as antiviral, antitumor, and anti-UV agents (Cerella et al., 2010; Groniger et al., 1999; Ponce et al., 2003). Indonesian tropical warm waters are known to be suitable for macroalgae growth. However, most macroalgae species are largely unexplored for its biological potentials. In this study, we evaluated the biological potentials of non-cultivated macroalgae found in most coastal areas of Indonesia such as ASE, AME, SPE, and SCE crude ethanol extracts.

Chromatographic profiles of macroalgae ethanol extracts shown the existence of various bioactive compounds (Fig. 1). Bioactive compound palmitic acid (C16:O) being the compound present in all macroalgae ethanol extracts. According to the literature, palmitic acid is predominant in macroalgae or seaweeds (Gressler et al., 2010). Alkaloids, flavonoids, terpenoids, polysaccharides, saponins, and others have been documented as natural bioactive products with potent pharmaceutical activities (Avato et al., 2017; Joshi et al., 2017). Our results revealed that different macroalgae species ethanol extracts exhibit different phytochemical profiles. This possibly affects the different biological activities of macroalgae extracts. Further evaluation of the extract solvent is needed to obtain the best pharmaceutical activity of macroalgae species. Pure drugs produced from plants

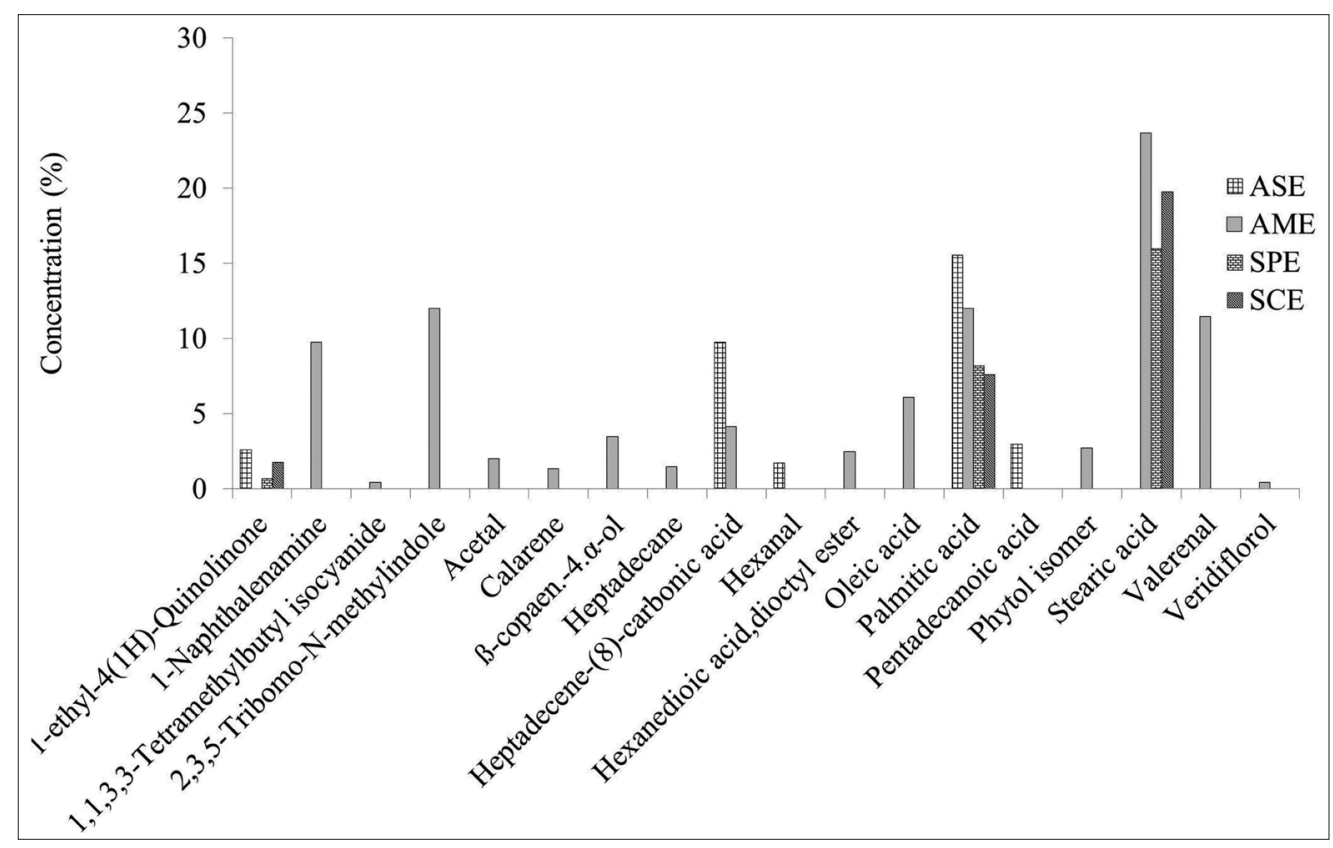

Figure 1. Chemical constitutents of macroalgae crude ethanol extracts analsyed with GC-MS spectrometry. 

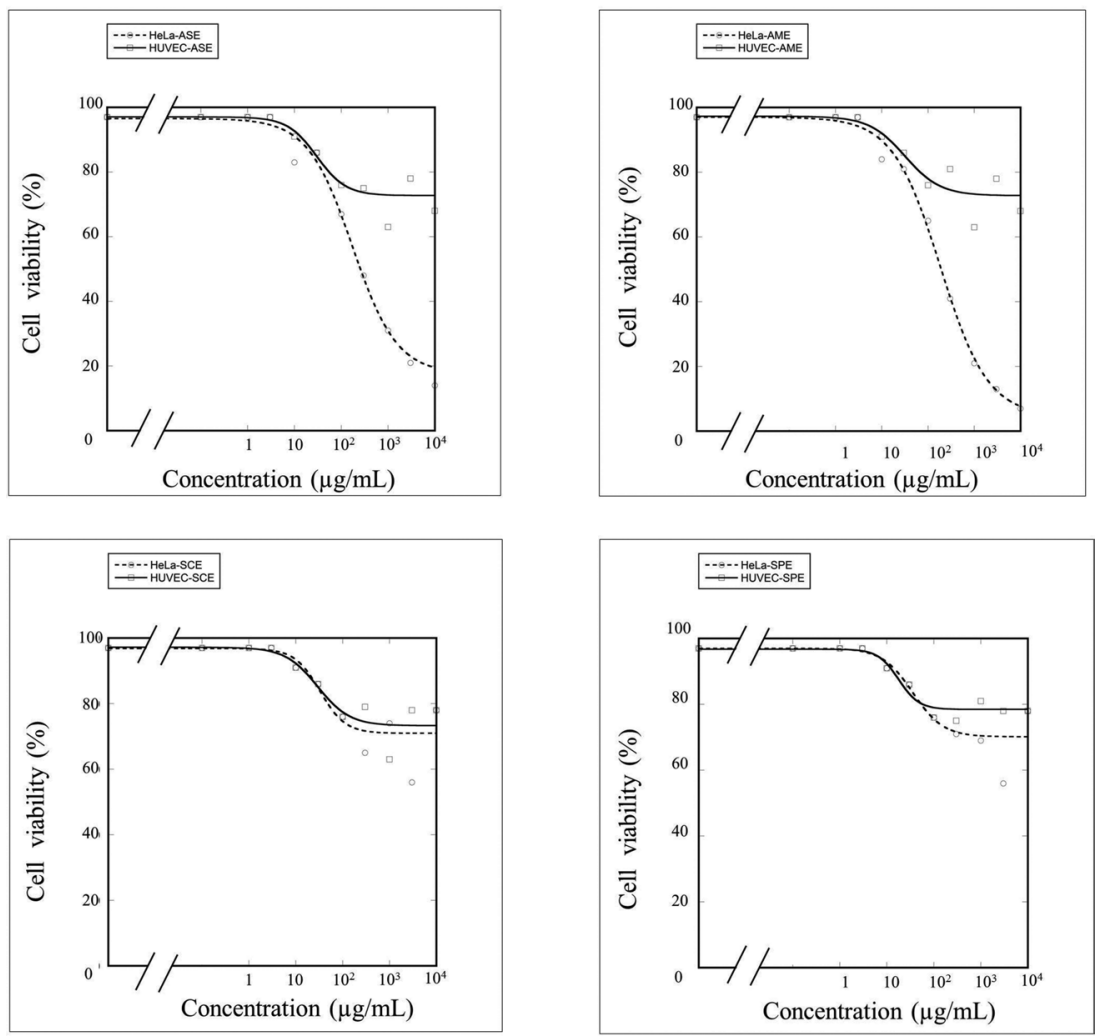

Figure 2. Cytotoxic assay of macroalgae crude ethanol extracts in HeLa and HUVEC cells analysed with MTT assay in $72 \mathrm{~h}$ treatment.

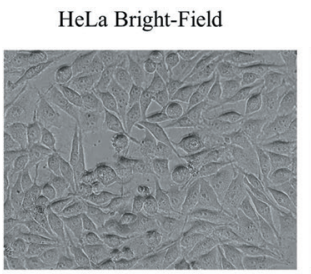

HUVEC Bright-Field

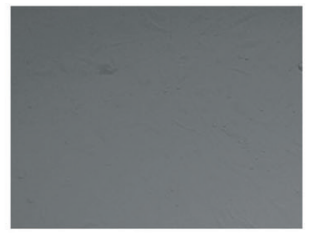

ASE
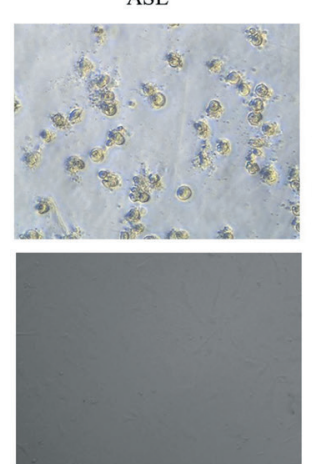

AME
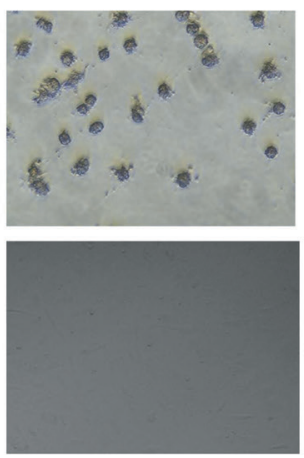

SPE
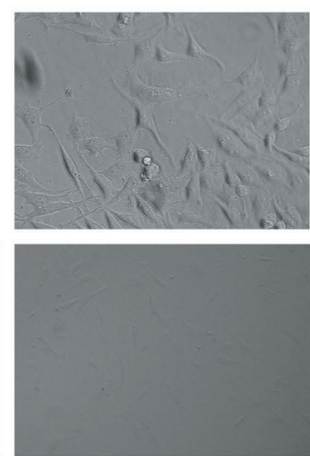

SCE
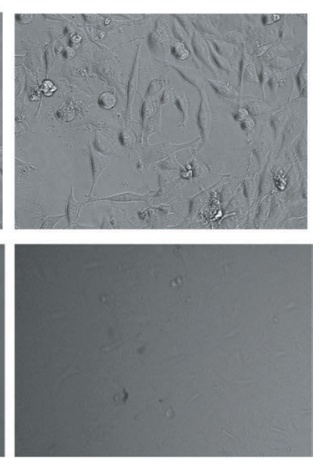

Figure 3. Morphological observation of HeLa and HUVEC cells treated with macroalgae crude ethanol extracts $(200 \mu \mathrm{g} / \mathrm{mL})$ for $72 \mathrm{~h}$.

rarely have the same degree of activity as the unrefined extract (Wagner and Ulrich-Merzenich, 2009). This phenomenon is attributed to the absence of interacting substances present in the extract. Hence, early screening of potential biological activities of crude extracts is needed to confirm further investigations toward purification of potential bioactive compounds.
The cytotoxic effects of macroalgae ethanol extracts were determined with MTT assay. Only ASE and AME were seen to exhibit cytotoxic activities in our tested macroalgae samples. The alcoholic extract of $A$. spicifera exhibits tumoricidal activity on Ehrlich's ascites carcinoma cells developed in mice at a dose of $20 \mathrm{mg} / \mathrm{kg}$ comparable to the standard drug, 5-fluorouracil 


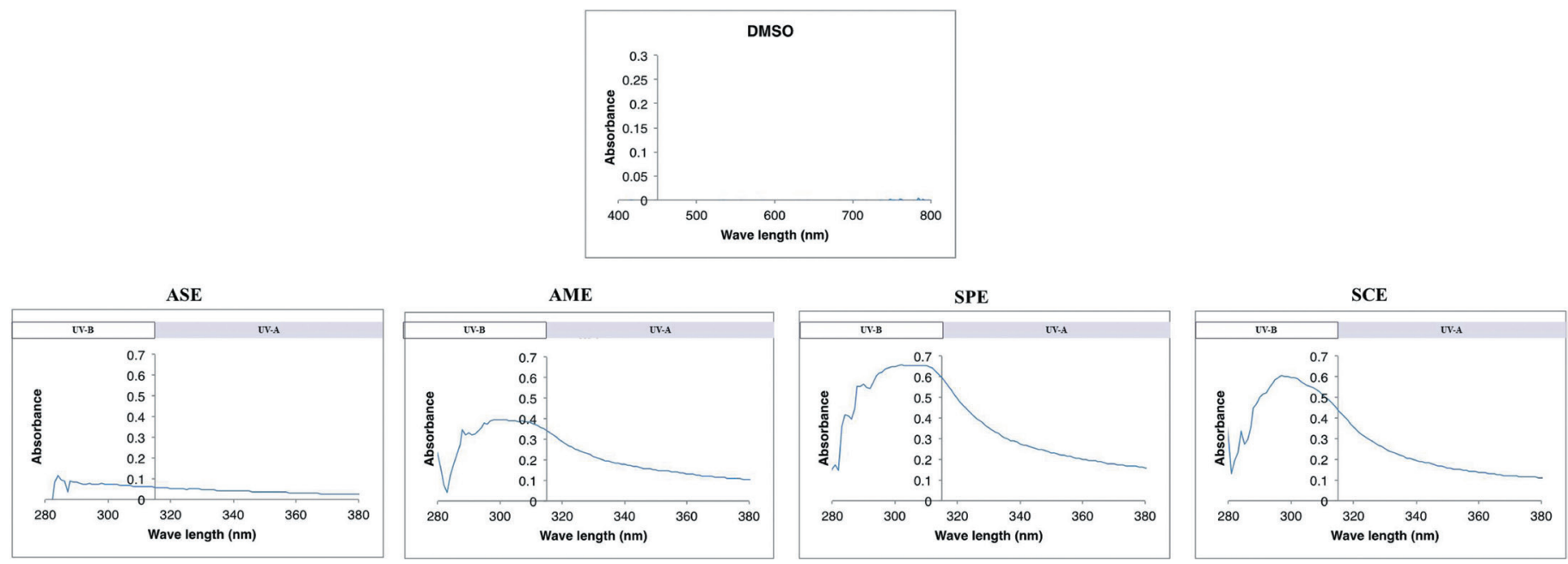

Figure 4. UV-VIS analyses of macroalgae ethanol extracts for determination of UV-absorbing capability.

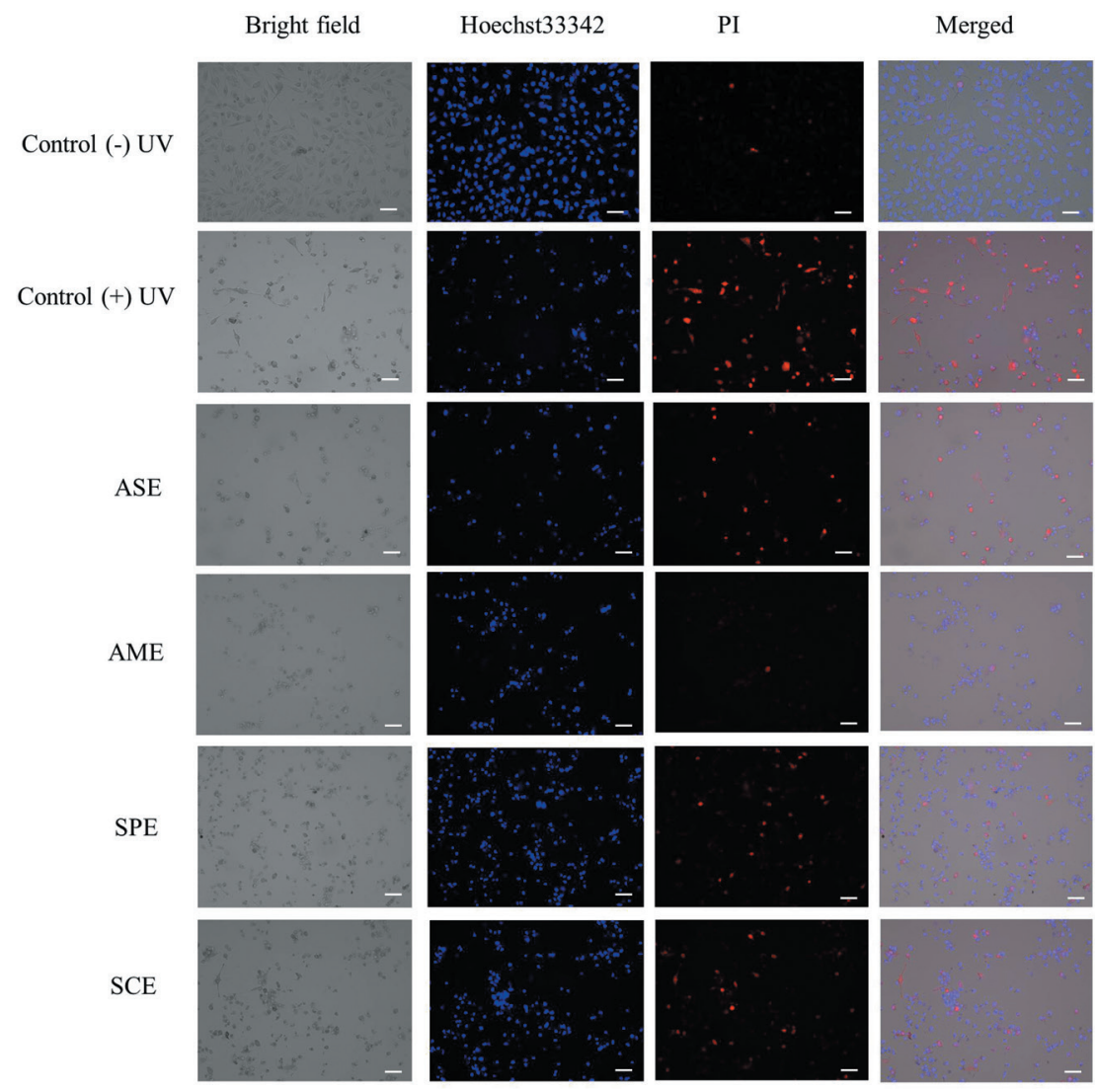

Figure 5. Fluorescence imaging of HeLa cells incubated with macroalgae ethanol extracts $(20 \mu \mathrm{g} / \mathrm{mL})$ followed by UV-B radiation for 3 mins. Blue cells indicate live/ dead cells stained with Hoechst33342. Red cells indicate dead cells stained with Propidium Iodide (PI). Scale $=100 \mu \mathrm{m}$.

(Vasanthi et al., 2004). However, this is the first report describing the cytotoxic activity of $A$. muscoides. We assumed that Sarggasum species would also demonstrate cytotoxic activities in HeLa cells, due to its fucoidan content (Atashrazm et al., 2015). However, SPE and SCE cytotoxic effects were not observable in HeLa and HUVEC cells. This result correlates with literature which reports that crude methanol extract of Sargassum filipendula also presented no antiproliferative activity under any of the tested concentrations in HeLa cells for 72 hours (Gomes et al., 2015). Hence, further investigation of the optimal extraction solvent for Sargassum species would be necessary for the determination of its potential pharmaceutical activities. In addition, all macroalgae extracts cytotoxic activity could not be determined in normal cell line HUVEC cells. However, further molecular analysis needs to be conducted for more established confirmation of this result. 


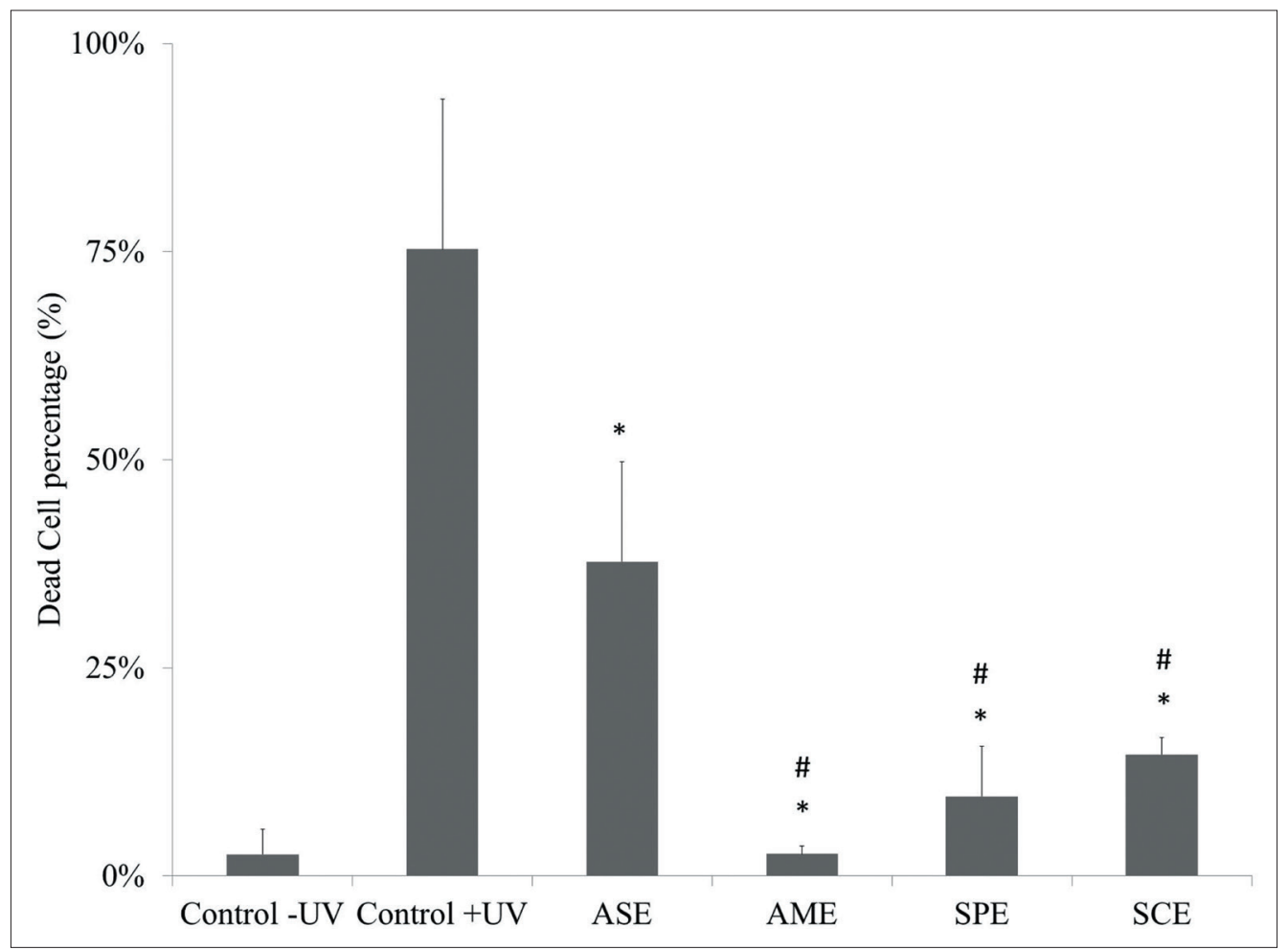

Figure 6. Dead cell percentage of HeLa cells incubated with macroalgae ethanol extracts $(20 \mu \mathrm{g} / \mathrm{mL})$ followed by UV-B radiation for 3 mins. $*$ indicates $\mathrm{P}<0.05$ significantly different compared to control $+\mathrm{UV}$; \# indicates $\mathrm{P}<0.05$ significantly different compared to ASE.

Our spectrophotometry results show that ethanol extract of AME, SPE, and SCE shown UV absorption from 280 to 320 $\mathrm{nm}$, which is the specific spectrum range of UV-B (Fig. 4). Only macroalgae ASE resulted in a lower absorbance peak in UV-B spectrum range. Addition to this research, we applied macroalgae ethanol extracts for the investigation of cytoprotective activity against UVB radiation. Previous reports have shown a widespread group of UV-absorbing compounds in algae such as mycrosporinelike amino acids. Sctonemins are frequently found in cyanobacteria and sporopollenin in some green algae. Polyphenolics such as phlorotannin are considered as UV inducible screening compounds in some macroalgae, especially red macroalgae such as Acanthophora (Pavia and Brock 2000; Pavia et al., 1997). A study by Lee et al. (2012) also reported that red algae Gloiopeltis furcata has the highest peaks between 280 and $360 \mathrm{~nm}$. However, other species evaluated did not show any UV absorption peaks. This suggests macroalgae species have diverse potentials in absorbing UV spectrum which would be interesting to explore in more advanced research.

HeLa cells exposed with UV-B radiation were seen to experience altered morphology and an increase of dead cells (Fig. 5). UV-B treated cells would also result in a flattened and shrinkage morphological features (Qin et al., 2018). Significant differences were seen in dead cell percentage after UV-B irradiation treatment between HeLa cells incubated with AME, SPE, and SCE compared with control cells and ASE-treated cells. Brown macroalgae Sargassum species has well been reported for its potential to inhibit UV-B radiation damage (Kim et al., 2012; Piao et al., 2014). Hence, further exploration of Sargassum species as a potential source of cytoprotective agents against UV radiation would be reasonable.

\section{CONCLUSION}

Our current findings show that the macroalgae crude ethanol extract exhibits diverse phytochemical profiles which affect its unique biological activity. ASE and AME demonstrated moderate selective cytotoxicity. However, cytotoxicity and antiproliferative activities of SPE and SCE were not observable in this study. SPE and SCE shown more significant cytoprotective activity compared with ASE and AME. Interestingly, AME demonstrated both antiproliferative and cytotoxic activity which implies its broad range of possible pharmaceutical applications. Further exploration of non-cultivated/wild Indonesian macroalgae would be interesting for the discovery of potential natural compounds.

\section{ACKNOWLEDGMENTS}

We thank the Indonesian Ministry of Research, Technology, and Higher Education for funding this research through the International Collaborative Research Grant Scheme.

\section{CONFLICT OF INTEREST}

The authors declare no conflict of interest.

\section{REFERENCES}

Alekseyenko TV, Zhanayeva SY, Venediktov AA, Zvyagintseva TN, Kuznetsova TA, Besednova NN, Korolenko TA. Antitumor and antimetastatic activity of fucoidan, a sulfated polysaccharide isolated from the Okhotsk sea Fucus evanescens brown alga. Bull Exp Biol Med, 2007; $143: 730-2$. 
Atashrazm F, Lowenthal RM, Woods GM, Holloway AF, Dickinson JL. Fucoidan and cancer: a multifunctional molecule with antitumoral potential. Mar Drugs, 2015; 13(4):2327-46.

Avato P, Migoni D, Argentieri M, Fanizzi FP, Tava A. Activity of saponins from medicago species against HeLa and MCF-7 Cell Lines and their capacity to potentiate cisplatin effect. Anticancer Agents Med Chem, $2017 ; 17: 1508-18$

Barbosa M, Valent2ão P, Andrade PB. Bioactive compounds from macroalgae in the new millennium: Implications for neurodegenerative diseases. Mar Drugs, 2014; 12:4934-72.

Bouhlal R, Haslin C, Chermann JC, Colliec-Jouault S, Sinquin C, Simon G, Cerantola S, Riadi H, Bourgougnon N. Antiviral activities of sulfated polysaccharides isolated from Sphaerococcus coronopifolius (Rhodophytha, Gigartinales) and Boergeseniella thuyoides (Rhodophyta, Ceramiales). Mar Drugs, 2011; 9:1187-209.

Butler MS. The role of natural product chemistry in drug discovery. J Nat Prod, 2004; 67:2141-53.

Cerella C, Sobolewski C, Dicato M, Diederich M. Targeting COX-2 expression by natural compounds: a promising alternative strategy to synthetic COX-2 inhibitors for cancer chemoprevention and therapy. Biochem Pharmacol, 2010; 80:1801-15.

Cho SH, Kang SE, Cho JY, Kim AR, Park SM, Hong YK, Ahn DH. The antioxidant properties of brown seaweed (sargassum siliquastrum) extracts. J Med Food, 2007; 10(3):479-85.

Cragg GM, Newman DJ, Snader KM. Natural products in drug discovery and development. J Nat Prod, 1997; 60:52-60.

Gomes DL, Telles CBS, Costa MSSP, Almeida-Lima J, Costa LS, Keesen TSL, Rocha HAO. Methanolic extracts from brown seaweeds Dictyota cilliolata and Dictyota mestrualis induce apoptosis in human cervical adenocarcinoma HeLa cells. Molecules, 2015; 20:6573-91.

Gressler V, Yokoya N, Fujii M, Colepicolo P, Filho J, Torres R, Pinto E. Lipid, fatty acid, protein, amino acid and ash contents in four Brazilian red algae species. Food Chem, 2010; 120:585-90.

Gröniger A, Sinha RP, Klisch M, Häder DP. Photoprotective compounds in cyanobacteria, phytoplankton and macroalgae - a database. J. Photochem. Photobiol. B Biol. 2000,58; 115-122.

Guiry MD, Guiry GM. AlgaeBase. World-wide electronic publication. National University of Ireland, Galway, 2018. Available via http://www.algaebase.org (Updated 4 July 2018; Accessed 2 October 2017).

Harborne JB, Nagooru MR. Phytomochemical methods: a guide to modern techniques of plant analysis. 2nd edition, Chapman and Hall, London, UK, pp 54-84, 1998.

Heo SJ, Jeon, YJ. Evaluation of diphlorethohydroxycarmalol isolated from Ishige okamurae for radical scavenging activity and its protective effect against $\mathrm{H}_{2} \mathrm{O}_{2}$-induced cell damage. Process Biochem, 2009; 44:412-8.

Joshi P, Vishwakarma RA, Bharate SB. Natural alkaloids as P-gp inhibitors for multidrug resistance reversal in cancer. Eur J Med Chem, 2017; 138:273-92.

Kawaguchi S, Hayashizaki, KI. Biodiversity studies on seaweeds and sea grasses in the coastal waters of Southeast Asia. In: Nishida S, Fortes MD, Miyazaki N (eds). Coastal Marine Science in Southeast Asia. Synthesis Report of the Core University Program of the Japan Society for the Promotion of Science: Coastal Marine Science (2001-2010), pp 49-57, 2011.

Kim JA, Ahn BN, Kong CS, Kim SK. Protective effect of chromene isolated form Sargassum horneri against UV-A induced damage in skin dermal fibroblasts. Exp Dermatol, 2012; 21(8):630-1.

Kim SK, Thomas NV, Li X. Anticancer compounds from marine macroalgae and their application as medicinal foods. Adv Food Nutr Res, 2011; 64:213-24

Kim EY, Choi YH, Lee JI, Kim IH, Nam TJ. Antioxidant Activity of Oxygen Evolving Enhancer Protein 1 Purified from Capsosiphon fulvescens.J.Food.Sci,2014;80(6):H1412-7.

Kintzios SE. Terrestrial plant-derived anticancer agents and plant species used in anticancer research. Crit Rev Plant Sci, 2006; 25:79-113.
Lee MH, Kim YK, Yoon NY, Shim KB, Aminina NM, Kadnikova IA, Lim,CW. Study on UV absorption materials derived from red algae Gloiopeltis fucatas and Mazzaella sp. in Russia. Fish Aquat Sci, $2012 ; 15: 361-3$.

Luo M, Shao B, Nie W, Wei XW, Li YL, Wang BL, He ZY, Liang $X$, Ye TH, Wei YQ. Antitumor and adjuvant activity of $\lambda$-carrageenan by stimulating immune response in cancer immunotherapy. Sci Rep, 2015; $5: 11062$

Mayer AMS, Glaser KB, Cuevas C, Jacobs RS, Kem W, Little RD, McIntosh JM, Newman DJ, Potts BC, Shuster DE. The odyssey of marine pharmaceuticals: a current pipeline perspective. Trends Pharmacol Sci, 2010; 31:255-65.

Na HJ, Moon PD, Lee HJ, Kim HR, Chae HJ, Shin T, Seo Y, Hong SH, Kim HM. Regulatory effect of atopic allergic reaction by Carpopeltis affinis. J Ethnopharmacol, 2005; 101:43-8.

Patridge E, Gareiss P, Kinch MS, Hoyer D. An analysis of FDAapproved drugs: natural products and their derivates. Drug Disc Today, 2015; 21:204-7.

Pavia H, Brock E. Extrinsic factors influencing phlorotannin production in the brown alga. Mar Ecol Prog Ser, 2000; 193:285-94.

Pavia H, Cervin G, Lindgren A, Aberg P. Effects of UV- B radiation and simulated herbivory on phlorotannins in the brown alga Ascophyllum nodosum. Mar Ecol Prog Ser, 1997;157:139-146.

Piao MJ, Kim KC, Zheng J, Yao CW, Cha JW, Boo SJ, Yoon WJ, Kang HK, Yoo ES, Koh YS, Ko MH, Lee NH, Hyun JW. The ethyl acetate fraction of Sargassum muticum attenuates ultraviolet B radiation-induced apoptotic cell death via regulation of AMPK- caspase-dependent signaling pathways in human HaCaT keratinocytes. Pharm Biol, 2014; 52(9):1110-8.

Ponce NM, Pujol CA, Damonte EB, Flores ML, Stortz CA. Fucoidans from the brown seaweed Adenocystis utricularis: extraction methods, antiviral activity and structural studies. Carbohydr Res, 2003; 338:153-65.

Prasedya ES, Miyake M, Kobayashi D, Hazama A. Carrageenan delays cell cycle progression in human cancer cells in vitro demonstrated by FUCCI imaging. BMC Complement Altern Med, 2016; 16:270.

Qin D, Ren R, Jia C, Lu Y, Yang Q, Chen L, Wu X, Zhu J, Guo Y, Yang P, Zhou Y, Zhu N, Bi B, Liu T. Rapamycin protects skin fibroblasts from ultraviolet $\mathrm{B}$-induced photoaging by suppressing the production of reactive oxygen species. Cell Physiol Biochem, 2018; 46:1849-60.

Shi D, Li X, Li J, Guo S, Su H, Fan X. Antithrombotic effects of bromophenol, an alga-derived thrombin inhibitor. Chinese J Oceanol Limnol, 2010; 28:96-8.

Sulistijo. Buku modul rumput laut (Macroalga). Pusat Penelitian Oceanografi Lembaga Ilmu Pengetahuan Indonesia, Jakarta, 2009.

Tarman K, Lindequist U, Wende K, Porzel A, Arnold N, Wessjohann LA. Isolation of a new natural product and cytotoxic and antimicrobial activities of extracts from fungi of Indonesian marine habitats. Mar Drugs, 2011; 9(3):294-306.

Vasanthi HR, Rajamanickam GV, Saraswathy A. Tumoricidal effect of the red algae Acanthophora spicifera on Ehrlich's ascites carcinoma in mice, Seaweed Res. UntilNet, 2004; 25:217-24.

Wagner H, Ulrich-Merzenich G. Synergy research: approaching a new generation of phytopharmaceuticals. Phytomedicine, 2009; 16:97-110.

Zamroni A, Yamao M. An assessment of farm-to-market link of Indonesian dried seaweeds: contribution of middlemen toward sustainable livelihood of small-scale fishermen in Laikang Bay. Afr J Agric Res, 2012; 7:4198-208.

How to cite this article:

Prasedya ES, Ariyana M, Hamdin CD, Nikmatullah A, Yoshie S, Miyake M, Kobayashi D, Hazama A, Sunarpi H. Evaluation of Indonesian selected macroalgae for their antitumor and cytoprotective activity. J App Pharm Sci, 2018; 8(11): 123-130. 